\title{
In Vitro Rhizome Production from Nodal Explants and Callus Formation of the Medicinal Plant Dioscorea oppositifolia $\mathbf{L}$.
}

\author{
R.Uma Maheswari ${ }^{1}$, A. Lakshmi Prabha ${ }^{2}$, V. Nandagopalan ${ }^{3}$ and V.Anburaja ${ }^{4}$ \\ ${ }^{1} \& 2$ Department of Plant Science, Bharathidasan University, Tiruchirappalli-24, India \\ ${ }^{3 \& 4}$ Department of Botany, National College, Tiruchirappalli-1. India
}

\begin{abstract}
In vitro Studies of wild yam also known as Dioscorea oppositifolia L. is reported. Direct organogenesis and indirect organogenesis of D. oppositifolia is achieved in this study. Shoot and root were produced from nodal explants with Murashige and Skoog (MS) medium supplemented with $0.5 \mathrm{mg} / \mathrm{l} \mathrm{6-}$ benzylaminopurine (BAP) and $0.1 \mathrm{mg} / \mathrm{l}$ NAA. Callus was successfully produced from leaf explants on Murashige and Skoog (MS) medium supplemented with $0.5 \mathrm{mg} / \mathrm{l}$ indole-3-butyric acid (IBA).Multiple shoots were initiated from callus in Murashige and Skoog (MS) medium supplemented with-2.0mg/l Naphthalene acetic acid (NAA) and $2.5 \mathrm{mg} / \mathrm{i}$ kinetin. Root induction was also achieved simultaneously from the base of the shoots in the same medium. Regenerants acclimatized in soil-rite showed vigorous shoot growth (within 2 weeks) and after 5 - 6 months were suitable for planting.
\end{abstract}

Key words: Dioscorea oppositifolia, diosgenin, nodal culture, callus culture.

\section{Introduction}

The genus Dioscorea includes over 600 species [3], and is of considerable economic importance. A number of Dioscorea wild species are the source of compounds used in the synthesis of sex hormones and corticosteroids and cultivated species are the source of food in some tropical countries [7]. These true yams are the source of agents used to treat such varied conditions as inflammation, joint pain, diabetes, infections and dysmenorrhea. The pharmacologically active components of the Dioscorea species include diosgenin, which is a steroidal saponin, and dioscin, a form of diosgenin with sugars attached [19] Plantlet regeneration in vitro for vegetative propagation of some economically important Dioscorea species has been achieved using nodal cuttings [1, 4, 5, 13, 15, 23], bulbils [2], zygotic embryos [22], meristem tips[14], immature leaves [12] and roots [21], the clonal propagation through in vitro production of microtubers in D. abyssinica [17], D. alata [9, $10,17], D$. batatas [11], D. composite [1] and D. floribunda [20]. The tubers of D. oppositifolia are used as an herbal tonic. It stimulates the stomach and spleen and has an effect on the lungs and kidneys. The tuber has been eaten for the treatment of poor appetite, chronic diarrhea, asthma, dry coughs, frequent or uncontrollable urination, diabetes and emotional instability. Externally, the tuber has been applied to ulcers, boils and abscesses. Leaf juice from $D$. oppositifolia can be used to treat snake bites and scorpion stings.

\subsection{Plant material}

\section{Materials And Methods}

Plants of Dioscorea oppositifolia were collected from the Sirumalai hills in Tamilnadu, India and the species was identified by comparing with the authenticated specimen deposited at the Rapinat Herbarium, St Joseph College, Trichy, and Tamilnadu.

\subsection{Direct organogenesis}

\subsubsection{Regeneration of Plantlet from Nodal Segments}

Nodal vine segments from 60 days old plants of field grown D. opositifolia were used are explants for initial culture Basal medium used for initial set of experiment for shoot proliferation consisted of MS salt with $3 \%(\mathrm{~W} / \mathrm{V})$ sucrose, and $0.8 \%(\mathrm{~W} / \mathrm{V})$ agar. The explants were cultured on MS medium supplemented with different concentration kinetin-BAP) with IBA, IAA, NAA present also at $0,0.1,0.5,1.25,2.5$ or $5.0 \mu \mathrm{M}$. In all cases, the $\mathrm{pH}$ of the media was adjusted to 5.8 before autoclaving at $121{ }^{\circ} \mathrm{C}$ for $15 \mathrm{~min}$.All cultures were incubated at $25^{\circ} \mathrm{C} \pm 2{ }^{\circ} \mathrm{C}$ under a 16 -h photoperiod at $63 \mathrm{~mol} \mathrm{~m}^{-2} \mathrm{~s}^{-1}$ PAR at plant level produced by Philips TDL fluorescent light tubes. There were at least ten replicates per treatment. For rooting, the in vitro micro shoot lets were inoculated onto the half-strength MS has media supplemented with NAA and BAP with different concentration $0,0.1,0.5,1.25,2.5$ or $5.0 \mu \mathrm{M}$.

\subsection{Indirect regeneration}

\subsubsection{Induction of callus from explants}

The explants were surface sterilized with $60 \%$ alcohol for $5 \mathrm{~min}$ and $0.1 \% \mathrm{HgCl}_{2}$ for $10 \mathrm{~min}$, then rinsed three times in sterilized water. Explants were place on agar- solidified culture medium in the culture tubes. The basal medium consisted of salts and vitamins of MS medium and solidified with $0.8 \%(\mathrm{w} / \mathrm{v})$ agar. 
The medium was adjusted to $\mathrm{pH} 5.8$ before adding agar, and then sterilized by autoclaving at $121^{\circ} \mathrm{C}$ for $15 \mathrm{~min}$. All the cultures were maintained at $25 \pm 2^{\circ} \mathrm{C}$ under $16 / 8 \mathrm{~h}$ light/ dark conditions. The leaf explants was cultured on MS medium supplemented with various concentration of auxins [NAA, IBA, and 2, 4-D ( $0.5-2.5 \mathrm{mg} / \mathrm{l})$ ] in combination with cytokinin [BAP and KIN $(0.5-2.5 \mathrm{mg} / \mathrm{l})$ ] for callus induction. The effect of growth regulators on callus induction response was studied and an effort was made to determine the appropriate growth regulator combination for optimal callus growth. Callus induction could be observed after $40-50$ days.

\subsection{Regeneration of Plantlet from Callus}

Callus was transferred to MS medium with various combination of auxins (NAA, 2, 4 - D) with cytokines (kinetin, BAP) at different concentration. The $\mathrm{pH}$ of medium was adjusted to 5.8. The cultures were incubated at $28 \pm 1{ }^{\circ} \mathrm{C}$ under $16 \mathrm{hr}$ photoperiod with cool white fluorescent.

\section{Results And Discussion}

In this paper we report results of a series of experiments carried out to determine the cultural conditions required to provide maximal in vitro shoot growth of commercial steroid lines of $D$. oppositifolia and also to induce and produce sizeable microtubers with high weight than others and can be used for the transfer of in vitro multiplied microplants to the field.

The effects of sucrose on in vitro plantlet growth and microtuberization of $D$. composita are presented in Table 2. On MS medium containing $30-40 \mathrm{gl}^{-1}$ sucrose, D. oppositifolia microtubers were not induced, whereas they were on the 70 and $80 \mathrm{gl}^{-1}$ sucrose treatments.

Sucrose levels $70 \mathrm{gl}^{-1}$ in culture media appeared to be a prerequisite for microtuber induction and optimal in vitro plantlet growth of $D$. oppositifola microplants. Those grown at high levels of sucrose (70 and $100 \mathrm{gl}^{-1}$ ) had between 300 to $450 \%$ greater microtuber fresh and dry weight increases and produced ca. 200 to $350 \%$ more shoots and nodes than microplants cultured on comparable MS medium containing $20 \mathrm{gl}^{-1}$ sucrose. Similar results were derived from microtuberisation of the aerial producing yam D. bulbifera. Microtuberization with this species was shown to occur only when shoot cultures were grown on culture media containing sucrose at $8-10 \%$ in the absence of growth regulators. Auxins, cytokinins and ABA are effective inducers of microtuberization in a number of different yam species cultured in vitro, although certain types are more effective than others for increasing microtuber formation CMS Media with greater than 50mg/l of sucrose were effective for inducing levels of microtuberization in this steroid yam $[8,16]$. The effects of cytokinins and auxins on morphogenesis of nodal segment explants are presented in tables $(1-3)$ and figures $(1-5)$.

Micro propagation of other yam species in a solid medium has been reported [6]. The dependence of cultured explants on bud break response and shoot multiplication has already been established and extensively discussed. This has also been recently reported in the case of micro propagation of other Yams like Dioscorea composita [1], Dioscorea batatas [11] and Dioscorea abyssinica [17].

In our investigation, microtuberization of Dioscorea oppositifolia were obtained with concentration of Kinetin $2 \mathrm{mg} / \mathrm{l}$ in combination with GA $3.5 \mathrm{mg} / \mathrm{l}$ and MS medium produced the fresh weights of microtubers concentration of BA $3.0 \mathrm{mg} / \mathrm{l}$ and GA $3.5 \mathrm{mg} / \mathrm{l}$ produced with highest the fresh weights of microtubers of 456.2 $\pm 1.0 \mathrm{mg}$ and minitubers were harvested ranging from $12-60 \mathrm{mg}$ fresh weight were obtained.This is the first report of producing microrhizome of fresh weight more than $400 \mathrm{mg} / \mathrm{l}$ in $D$. oppositifolia. It influences accumulation of raised levels of diosgenin.

\section{Conclusion}

Direct organogenesis and indirect organogenesis of D. oppositifolia is achieved in this study. Shoot and root were produced from nodal explants with Murashige and Skoog (MS) medium supplemented with $0.5 \mathrm{mg} / \mathrm{l}$ 6-benzylaminopurine (BAP) and $0.1 \mathrm{mg} / \mathrm{l}$ NAA. Callus was successfully produced from leaf explants on Murashige and Skoog (MS) medium supplemented with $0.5 \mathrm{mg} / \mathrm{l}$ indole-3-butyric acid (IBA).Multiple shoots were initiated from callus MS medium supplemented with-2.0mg/l Naphthalene acetic acid (NAA) and $2.5 \mathrm{mg} / \mathrm{i}$ kinetin. Root induction was also achieved simultaneously from the base of the shoots in the same medium. Regenerants acclimatized in soil-rite showed vigorous shoot growth (within 2 weeks) and after 5 - 6 months were suitable for planting.

\section{Acknowledgements}

Our sincere thank to University Grant Commission, NewDelhi-110002, for providing financial support of R.Uma Maheswari for Ph.D Programme.

\section{References}

[1] S. Alizadeh, , S. H. Mantell and A. M. Viana, In vitro shoot culture and microtuber induction in the steroidal yam Dioscorea composite Hemsl. Plant Cell Tissue Organ Cult. 53, 1998, 107-112.

[2] M.P. Asokan, , S.K. O'Hair and Litz, In vitro plant development from bulbil explants of two Dioscorea species. Hortic. Sci.,18, 1983, 702-703.

[3] E.S. Ayensu, Anatomy of the monocotyledons VI Dioscoreales Oxford Press, Oxford.p.82. Coursey, D.G.1976. Yams, Dioscorea spp. (Dioscoreaceae) In: Simmonds ED (Ed) Evolution of crop plants. Longman,London, 1972, pp.70-74.

[4] H.C. Chaturvedi, Propagation of Dioscorea floribunda in vitro culture of single node segments. Curr. Sci., 44, 1975, 839-841. 
[5] Y. Chen, J. Fan, F. Yi, Z. Luo, and Y. Fu, Rapid clonal propagation of Dioscorea zingiberensis. Plant Cell Tissue Organ Cult. 73, 2003, 75-80.

[6] E. P. Chu, and R. C. L. Figueiredo Ribeiro, Growth and carbohydrate changes in shoot cultures of Dioscorea species as influenced by photoperiod, exogenous sucrose and cytokinin concentrations. Plant Cell Tiss. Org. Cult. 70, 2002, 241-249.

[7] D.G. Coursey, Yams. Longman, Green and Co, London, 230p. Forsyth, C. and Van Staden,J.1982. An improved method of in vitro propagation of Dioscorea bulbifera. Plant Cell Tissue Organ Cult., 1, 1967, 275-281.

[8] C Forsyth and J Van Staden, Tuberization of Dioscorea bulbifera stem nodes in culture. J. Plant Physiol. 115: 79-83 Gamborg OL, Eveleigh DE (1968) Culture methods and detection of glucanases in suspension cultures of wheat and barley. Can. J. Biochem. 46, $1984,417-421$.

[9] A. Jasik and S Mantell, Effects of jasmonic acid and its methylester on in vitro microtuberisation of three food yam (Dioscorea) species. Plant Cell Rep., 19, 2000, 863-867.

[10] J.L.John, W.H. Courtney and D.R. Decoteau, The influence of plant growth regulators and light on microtuber induction and formation in Dioscorea alata L. cultures. Plant Cell Tissue Organ Cult. 34, 1993, 245-252.

[11] Y. Koda and Y. Kikuta, Possible involvement of jasmonic acid in tuberization of yam plants. Plant Cell Physiol., 32, 1991, 629633.

[12] H. Kohmura, H. Araki and M. Imoto, Micropropagation of 'yamatoimo' Chinese Yam (Dioscorea opposita) from immature leaves. Plant Cell Tissue Organ Cult.. 40, 1995, 271-276.

[13] G. Lakshmisita, R. K. Bammi, and G. S. Randhawa, Clonal propagation of Dioscorea floribunda by tissue culture. J. Hortic. Sci., 51, 1976, 551-554.

[14] B. Malaurie, O. Pungu, and M. F. Trouslot, Effects of growth regulators concentrations on morphological development of meristem-tips in Dioscorea cayenensis, D .rotundata complex and D. praehensilis. Plant Cell Tiss. Org. Cult., 42, $1995,215-21$.

[15] S. H. Mantell, S. Q. Haque and A. P. Whithall, Clonal propagation of Dioscorea alata L. and Dioscorea rotundata Poir yams by tissue culture. J. Hortic. Sci., 51: 95-98. Alizadeh, S., Mantell, S.H. and Viana, A.M. 1998. In vitro shoot culture and microtuber induction in the steroidal yam Dioscorea composite Hemsl. Plant Cell Tissue Organ Cult.,53, 1978, 107-112.

[16] S. H. Mantell and S. A. Hugo, Effects of photoperiod, mineral medium strength, inorganic ammonium, sucrose and cytokinin on root, shoot and microtuber development in shoot cultures of Dioscorea alata L. and D. bulbifera L. Yams. Plant Cell Tissue Organ Cult. 16, 1989, 23-37.

[17] J. Martine and M. Cappadocia, In vitrotuberization in Dioscorea alata L. 'Brazo fuerte'and 'Florido' and D. abyssinica Hoch. Plant Cell Tissue Organ Cult. 26, 1991, 147-152.

[18] T Murashige and F Skoog, A revised medium for rapid growth and bioassays with tobacco tissue cultures. Physiol. Plant. 15, 1962, 473-497.

[19] J. M. S. Ramberg and S Nugent, History and uses of Dioscorea as a Food and Herbal Medicine. Glycosci. Nutr., 3(6), $2002,1-5$.

[20] J. Sengupta, G. C. Mitra and A. K. Sharma, Organogenesis and tuberization in cultures of Dioscorea floribunda. Plant Cell Tissue Organ Cult. 3, 1984, 325-331.

[21] C. T. Twyford and S. H. Mantell, Production of somatic embryos and plantlets from root cells of Greater yam. Plant Cell Tissue Organ Cult. 46, 1996, 17-26.

[22] A. M. Viana and S. H. Mantell, Callus induction and plant regeneration from excised zygotic embryos of the seed propagated yams Dioscorea composita hemsl. and D.cayenensis Lam. Plant Cell Tissue Organ Cult.,16, 1989, 113-122.

[23] Y. C. Yan, Q. I. Lin Hh, Dai, and Q. Q. Huang, Studies on tissue culture and rapid propagation of Dioscorea zingiberensis. J Scichuan University (Natural Science Edition) 39, 2002, 136-140.

Table 1: Direct organogenesis from nodal explants with different auxin and cytokinin concentrations

\begin{tabular}{|c|c|c|c|}
\hline $\begin{array}{c}\text { MS+Growth } \\
\text { Regulators } \\
\text { Mg/1 }\end{array}$ & Frequency \% & Shoot length ${ }^{1}(\mathrm{Cm})$ & Root Length ${ }^{1}(\mathbf{C m})$ \\
\hline $\begin{array}{c}\text { Basal MS } \\
\text { NAA+Kinetin } \\
0.5+0.1 \\
0.1+0.5 \\
1.5+1.0 \\
2.0+1.5 \\
2.5+2.0\end{array}$ & $\begin{array}{c}0.0 \\
80.0 \\
84.6 \\
83.3 \\
90.5 \\
89.0\end{array}$ & $\begin{array}{c}0.0 \\
2.5 \pm 0.5 \\
2.3 \pm 1.2 \\
4.0 \pm 0.5 \\
5.0 \pm 0.5 \\
4.5 \pm 0.5\end{array}$ & $\begin{array}{l}0.0 \\
0.0 \\
0.0 \\
0.0 \\
0.0 \\
0.0\end{array}$ \\
\hline $\mathrm{BAP}+\mathrm{NAA}$ & & & \\
\hline $\begin{array}{l}0.5+0.1 \\
0.1+0.5 \\
1.5+1.0 \\
2.0+1.5 \\
2.5+2.0 \\
3.0+2.5\end{array}$ & $\begin{array}{l}80.0 \\
84.6 \\
83.3 \\
89.3 \\
91.3 \\
88.0\end{array}$ & $\begin{array}{l}2.5 \pm 0.5 \\
2.3 \pm 1.2 \\
4.0 \pm 0.5 \\
5.0 \pm 0.5 \\
5.5 \pm 0.5 \\
4.9 \pm 0.5\end{array}$ & $\begin{array}{l}0.5 \pm 0.5 \\
1.0 \pm 0.3 \\
1.5 \pm 0.5 \\
2.0 \pm 0.3 \\
2.5 \pm 0.5 \\
2.0 \pm 1.0\end{array}$ \\
\hline $\begin{array}{c}\text { BAP+IBA } \\
0.5+0.1 \\
0.1+0.5 \\
1.5+1.0 \\
2.0+1.5 \\
2.5+2.0\end{array}$ & $\begin{array}{l}98.6 \\
98.0 \\
99.0 \\
99.0 \\
98.6\end{array}$ & $\begin{array}{l}2.5 \pm 0.5 \\
2.3 \pm 0.5 \\
4.0 \pm 0.5 \\
6.0 \pm 0.5 \\
3.4 \pm 0.5\end{array}$ & $\begin{array}{l}2.0 \pm 0.2 \\
2.7 \pm 0.2 \\
3.5 \pm 0.2 \\
4.2 \pm 0.1 \\
3.0 \pm 0.3\end{array}$ \\
\hline
\end{tabular}

Table2: Effect of sucrose concentration on in vitro tuber formation MS Medium supplemented with BA + GA3 - 3.0 +3.5 mg/l

\begin{tabular}{|c|c|c|c|}
\hline S.No & $\begin{array}{c}\text { Sucrose } \\
\text { concentration(gm/1) }\end{array}$ & $\begin{array}{c}\text { Tuber } \\
\text { No }\end{array}$ & $\begin{array}{c}\text { Tuber } \\
\text { weight(mg) }\end{array}$ \\
\hline 1 & 10 & $1.0 \pm 0.0$ & $12.6 \pm 0.6$ \\
\hline 2 & 20 & $1.0 \pm 0.0$ & $15.2 \pm 06$ \\
\hline 3 & 30 & $2.0 \pm 0.0$ & $50.4 \pm 1.0$ \\
\hline 4 & 40 & $2.0 \pm 0.0$ & $51.1 \pm 0.5$ \\
\hline 5 & 50 & $3.0 \pm 0.0$ & $101.7 \pm 0.5$ \\
\hline 6 & 60 & $3.0 \pm 0.0$ & $129.0 \pm 2.0$ \\
\hline 7 & 70 & $4.0 \pm 0.0$ & $152.8 \pm 1.4$ \\
\hline 8. & 80 & $4.0 \pm 0.0$ & $420.8 \pm 1.4$ \\
\hline 9. & 90 & $3.0 \pm 0.0$ & $370.0 \pm 0.5$ \\
\hline
\end{tabular}

WWW.iosrjournals.org 
Means are calculated by Post-Hoc Multiple Comparison tests and the mean difference is significant at the 0.05 level.

Table 3: Effect of growth hormone on Callus production

\begin{tabular}{|c|c|c|c|}
\hline $\begin{array}{c}\text { Hormone } \\
\text { Concentration } \\
2,4-\mathrm{D}\end{array}$ & Callus No & Response\% & $\begin{array}{c}\text { Mass } \\
\text { weight(mg) }\end{array}$ \\
\hline 0.1 & 3 & 98.6 & $3.5 \pm 0.3$ \\
0.5 & 3 & 98.0 & $5.3 \pm 0.5$ \\
1 & 3 & 99.0 & $9.0 \pm 0.0$ \\
1.5 & 3 & 99.0 & $14.5 \pm 0.0$ \\
2.0 & 4 & 98.6 & $12.5 \pm 0.1$ \\
\hline NAA & 3 & 99.00 & $5.0 \pm 0.2$ \\
0.1 & 3 & 99.00 & $6.7 \pm 0.5$ \\
0.5 & 3 & 99.00 & $7.9 \pm 0.0$ \\
1.0 & 4 & 99.00 & $12.2 \pm 0.1$ \\
1.5 & 5 & 99.00 & $13.5 \pm 0.0$ \\
2.0 & & & \\
& & & \\
\hline
\end{tabular}

Means are calculated by Post-Hoc Multiple Comparison tests and the mean difference is significant at the 0.05 level.

Figure 1: Invitro Propogation of Dioscorea oppositifolia L. from Nodal explants

(A)

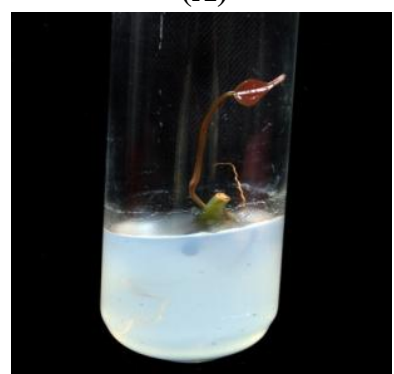

(B)
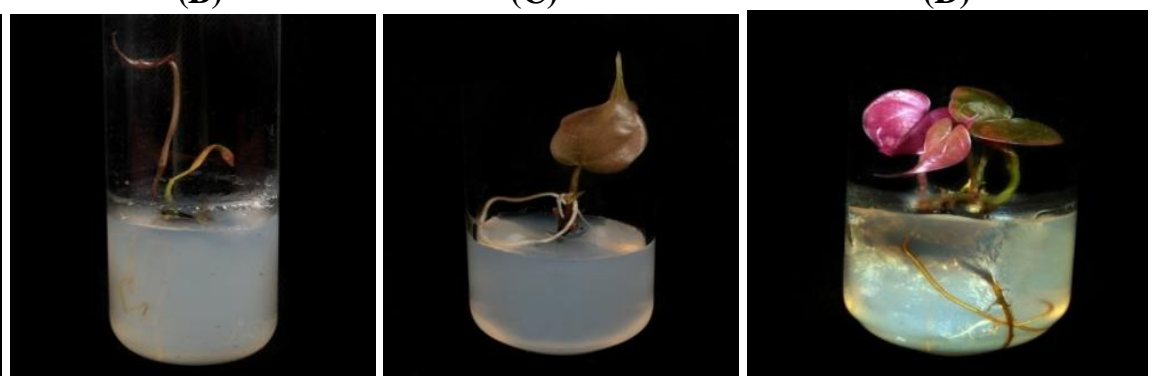

A) $\quad$ MS + Growth Regulators - NAA+kinetin - 2.0+1.5 mg/l after 15 days

B) $\quad$ MS + Growth Regulators -BAP+ NAA $-2.0+1.5 \mathrm{mg} / \mathrm{l}$ after 10 days

C) $\mathbf{M S}+$ Growth Regulators - BAP+ NAA - $2.5+2.0 \mathrm{mg} / 1$ after 15 days

D) $\quad$ MS + Growth Regulators - BAP+ IBA - 2.0+1.5 mg/l after 25 days

Figure 2: MS + Growth Regulators - BAP+ IBA - 2.5+2.0mg/l after35 day

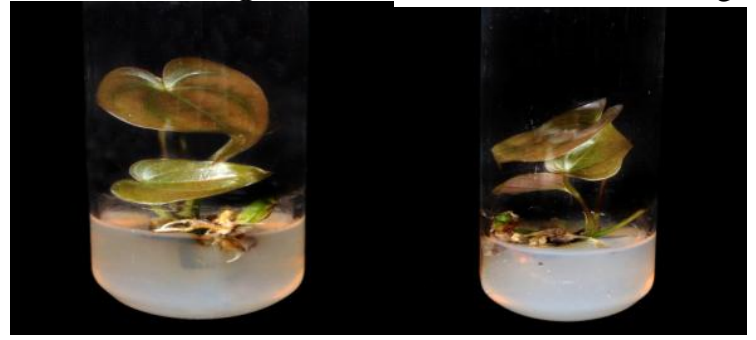

Figure 3: Callus Production from leaf Explants -MS + Growth Regulators - 2,4 D 1.5 mg/l

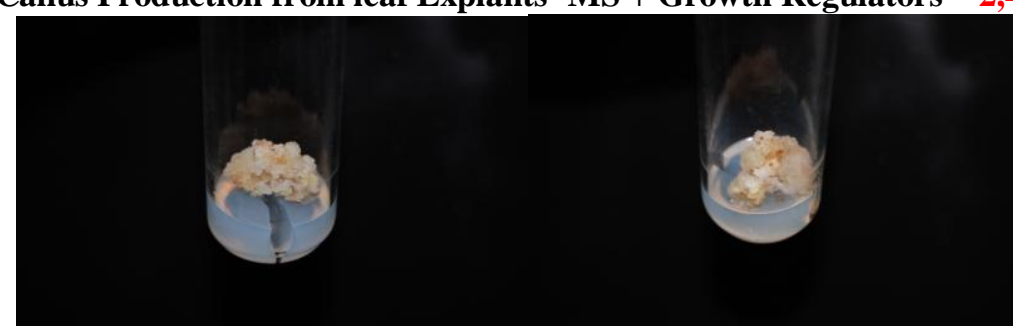

www.iosrjournals.org 
In Vitro Rhizome Production From Nodal Explants And Callus Of A Medicinal Plant Dioscorea

Figure 4: Invitro- rhizome formation from nodal Explants-MS+ BA+ GA3-3.0+3.5 mg/l after 35 days.
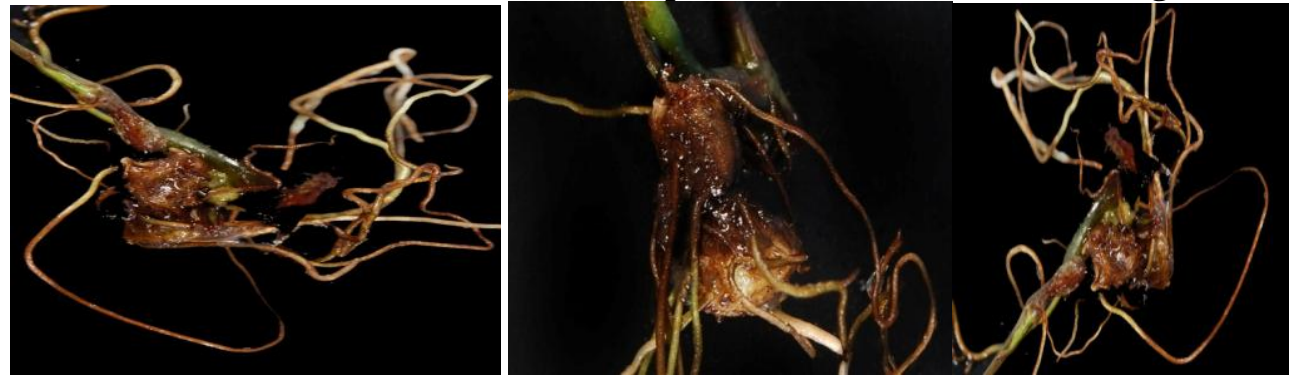

Figure 5: Invitro- rhizome formation from nodal Explants-MS+ BA+ GA3-3.0+3.5 mg/l after 25 days.
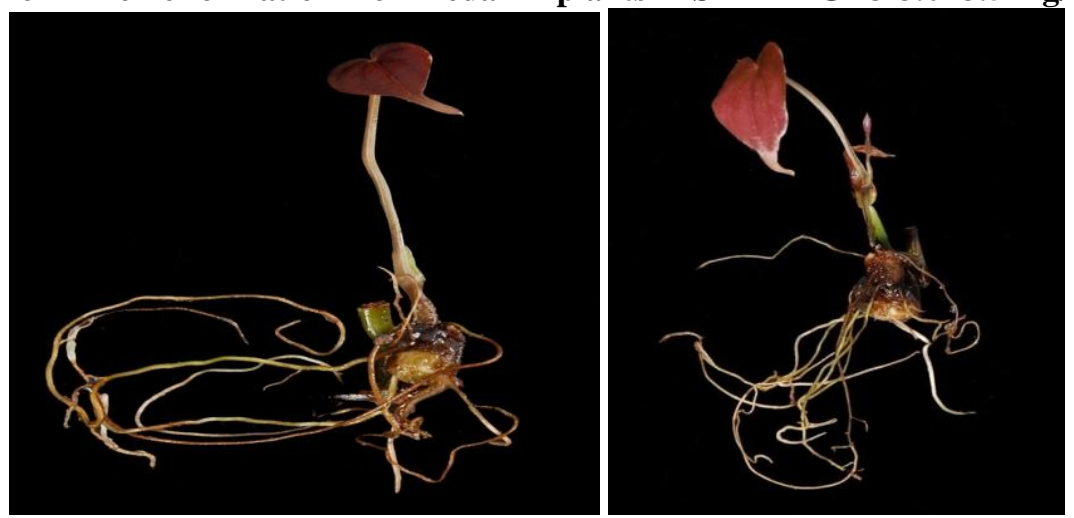

$* * * * *$ 